\title{
Is the southern Benguela a significant \\ regional sink of $\mathrm{CO}_{2}$ ?
}

AUTHORS:

Luke Gregor ${ }^{1}$

Pedro M.S. Monteiro',

\section{AFFILIATIONS:}

${ }^{1}$ Department of Oceanography, University of Cape Town, Cape Town, South Africa

${ }^{2} O$ cean Systems and Climate Group, CSIR, Stellenbosch, South Africa

\section{CORRESPONDENCE TO: \\ Luke Gregor}

EMAIL:

lukegre@gmail.com

\section{POSTAL ADDRESS:}

Department of Oceanography, University of Cape Town, Private Bag, Rondebosch 7700, South Africa

\section{DATES:}

Received: 13 June 2012

Revised: 05 Dec. 2012

Accepted: 17 Jan. 2013

\section{KEYWORDS:}

southern Benguela; eastern boundary; carbon dioxide; $\mathrm{CO}_{2}$; remineralisation

\section{HOW TO CITE:}

Gregor L, Monteiro PMS. Is the southern Benguela a significant regional sink of $\mathrm{CO}_{2}$ ? S Afr J Sci. 2013;109(5/6), Art. \#0094, 5 pages. http://dx.doi.org/10.1590/ sajs.2013/20120094
This study was undertaken to characterise the seasonal cycle of air-sea fluxes of carbon dioxide $\left(\mathrm{CO}_{2}\right)$ in the southern Benguela upwelling system off the South African west coast. Samples were collected from six monthly cross-shelf cruises in the St. Helena Bay region during 2010. $\mathrm{CO}_{2}$ fluxes were calculated from $\mathrm{pCO}_{2}$ derived from total alkalinity and dissolved inorganic carbon and scatterometer-based winds. Notwithstanding that it is one of the most biologically productive eastern boundary upwelling systems in the global ocean, the southern Benguela was found to be a very small net annual $\mathrm{CO}_{2}$ sink of $-1.4 \pm 0.6 \mathrm{~mol}$ $\mathrm{C} / \mathrm{m}^{2}$ per year (1.7 Mt C/year). Regional primary productivity was offset by nearly equal rates of sediment and sub-thermocline remineralisation flux of $\mathrm{CO}_{2}$, which is recirculated to surface waters by upwelling. The juxtaposition of the strong, narrow near-shore out-gassing region and the larger, weaker offshore sink resulted in the shelf area being a weak $\mathrm{CO}_{2}$ sink in all seasons but autumn $\left(-5.8,1.4\right.$ and $-3.4 \mathrm{mmol} \mathrm{C} / \mathrm{m}^{2}$ per day for summer, autumn and winter, respectively).

\section{Introduction}

Over the last 200 years, atmospheric carbon dioxide $\left(\mathrm{CO}_{2}\right)$ concentrations have risen by $40 \%$ as a result of anthropogenic emissions from fossil fuel combustion and land use changes. ${ }^{1}$ Nearly $50 \%$ of anthropogenic emissions has been taken up by the oceans, ${ }^{2}$ acting as a natural mitigation mechanism against greenhouse warming. Recent estimates have found that the global oceans take up $-2.2 \mathrm{Gt} \mathrm{C/year,}{ }^{3}$ but this amount excludes that of the continental margins, which are estimated to have an annual uptake of up to $-0.36 \mathrm{Gt} \mathrm{C} / \mathrm{year}^{4}{ }^{4} \mathrm{The}$ continental margins could potentially play an important role as anthropogenic $\mathrm{CO}_{2}$ sinks on national or regional scales, especially in areas where a significant proportion of the primary productivity carbon is naturally exported to the open ocean. ${ }^{5}$

This potential role could be particularly important to South Africa, the 13th largest $\mathrm{CO}_{2}$ emitter (119 Mt C/year). ${ }^{6}$ Several natural ecosystems have been identified as possible $\mathrm{CO}_{2}$ mitigation mechanisms, the broader categories being the terrestrial and marine biospheres. It is estimated that indigenous terrestrial ecosystems would realistically sequester 1-12 Mt C/year and would be effective as an active sink for only 30 years. ${ }^{7}$ Marine ecosystems may offer a more sustainable natural sequestration alternative. In recent years, marine ecosystems have received increased interest in this area, and have been dubbed 'blue carbon sinks'. ${ }^{8}$ The potential of blue carbon sinks lies predominantly in the conservation and rehabilitation of estuarine ecosystems such as mangrove forests, seagrasses and salt marshes. ${ }^{8}$ Shelf ecosystems are considered modest sinks in comparison to the aforementioned, but given the extent of the South African coastline, shelf carbon sequestration could be significant on a national scale. The Benguela upwelling system, the region of interest in this study, is considered a highly productive eastern boundary upwelling system, with the potential of being a $\mathrm{CO}_{2}$ sink. ${ }^{9} \mathrm{~A}$ study on the drivers of the air-sea $\mathrm{CO}_{2}$ fluxes in the southern Benguela was undertaken to better understand this system and to provide insight to this system being a regional sink and the sensitivities thereof.

The southern Benguela makes up the majority of the South African west coast, extending from $30^{\circ} \mathrm{S}$ to $35^{\circ} \mathrm{S}$. This eastern boundary upwelling system is a highly productive shelf ocean (with an average annual rate of $54 \mathrm{mmol}$ $\mathrm{C} / \mathrm{m}^{2}$ per day $)^{10}$ driven by equatorward alongshore winds. Seasonality in the southern Benguela is driven by the meridional migration and intensification of the South Atlantic Anti-Cyclone (SAAC). ${ }^{11}$ The southernmost extent of the SAAC occurs during summer months, resulting in alongshore winds favourable to upwelling. Northward migration of the SAAC and the weakening of the low pressure trough over the sub-continent during winter weakens the intensity of upwelling winds and allows mid-latitude cyclones to pass further north, which strengthen downwelling conditions. This seasonal forcing results in changes to the physics, chemistry and biology of the southern Benguela upwelling system, and thus changes in $\mathrm{CO}_{2}$ flux. ${ }^{9}$

Previous studies on the air-sea $\mathrm{CO}_{2}$ fluxes of the Benguela have found the region to be an annual sink of -1.70 (in 1994 and 1995) and -2.02 Mt C/year in 2005.,12 González-Dávila et al. ${ }^{13}$ reported large interannual variability in the Benguela south of $32^{\circ} \mathrm{S}$ during 2006 and 2007 (-1.17 and $-3.24 \mathrm{~mol} \mathrm{C} / \mathrm{m}^{2}$ per year, respectively), where the region was reportedly a continuous sink. This study provides a mechanistic perspective on the seasonality of contemporary air-sea $\mathrm{CO}_{2}$ fluxes in the southern Benguela by analysis of the marine carbonate system and nutrients.

\section{Methods}

Water samples were collected for six months (January, April, May, June, August and September) during 2010 along the St. Helena Bay Monitoring Line (SHBML). A conductivity, temperature and depth rosette with General Oceanics-Niskin bottles was lowered to various depths at each of the 12 stations (Figure 1). Samples were analysed for dissolved inorganic carbon (DIC) and total alkalinity (TA) using a Versatile Instrument for the Determination of Titration Alkalinity and Total Carbon (VINDTA 3C) by Marianda (Kiel, Germany). ${ }^{14}$ The precision achieved for DIC and TA was $\pm 3.7 \mu \mathrm{mol} / \mathrm{kg}$ and $2.5 \mu \mathrm{mol} / \mathrm{kg}$, respectively. Partial pressure of $\mathrm{CO}_{2}\left(\mathrm{pCO}_{2}\right)$ was calculated from DIC and TA using dissociation constants by Dickson and Millero ${ }^{15}$. A propagation of error analysis of $\mathrm{pCO}_{2}$ resulted in 
an error of $\pm 20 \mu \mathrm{atm}$. Nitrate, phosphate and silicate were collected and analysed using methods described by Grasshoff ${ }^{16}$.

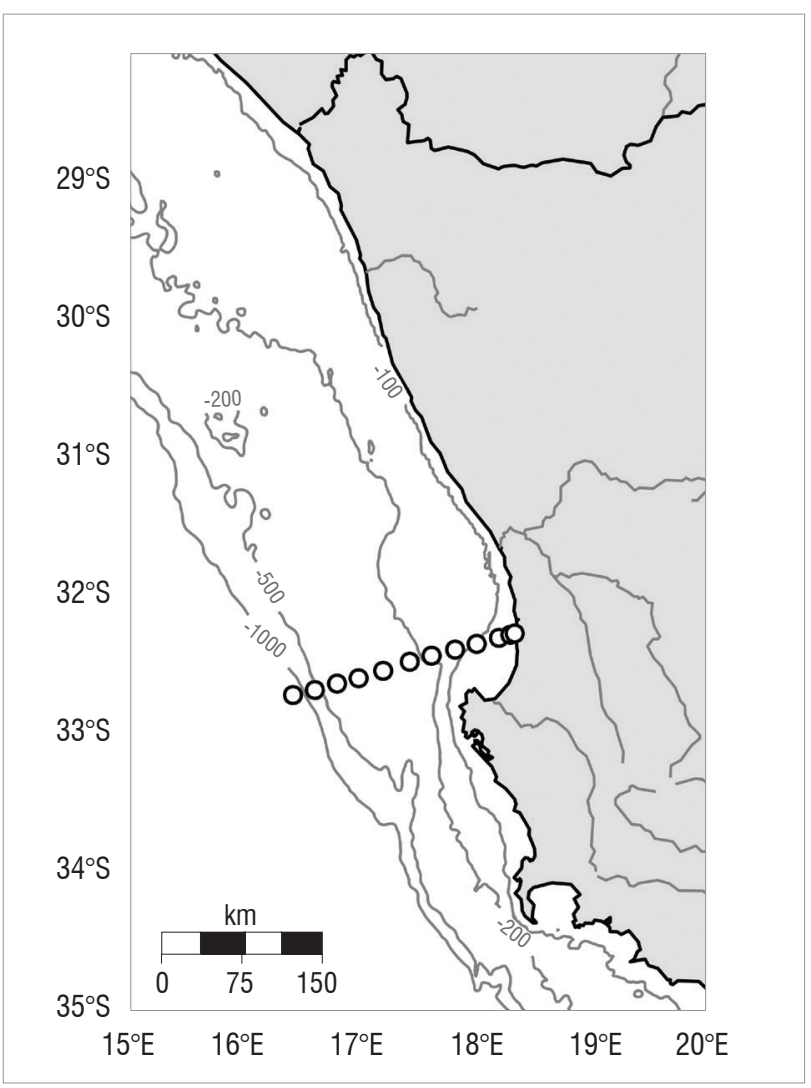

Figure 1: A map of the study region. The southern Benguela extends from $30^{\circ} \mathrm{S}$ to $35^{\circ} \mathrm{S}$ with the $500-\mathrm{m}$ isobaths marking the offshore boundary. The markers show the location of the 12 stations where samples were taken.
Sea-air $\mathrm{CO}_{2}$ flux was calculated using:

$$
F=k_{w} \cdot K_{0} \cdot \Delta p \mathrm{CO}_{2}^{\text {sea-air }}
$$

Equation 1

where $k_{w}$ is the gas transfer velocity, ${ }^{17} K_{0}$ is the solubility of $\mathrm{CO}_{2}$ in seawate ${ }^{18}$ and $\triangle \mathrm{pCO}_{2}$ is the difference between oceanic and atmospheric $\mathrm{pCO}_{2}$. Atmospheric $\mathrm{pCO}_{2}$ was considered to be the same as that measured at Cape Point. ${ }^{2}$ The gas transfer velocity $\left(k_{w}\right)$ was calculated using the empirical parameterisation by Wanninkhof et al. ${ }^{17}$ and Atlas Cross-Calibrated Multi-Platform wind product (CCMP winds). ${ }^{19}$ The gas transfer velocity was calculated using daily averaged winds. The flux was calculated by interpolating $\triangle \mathrm{pCO}$ over the entire year. Calculations of $\mathrm{CO}_{2}$ fluxes for the southern Benguela used an area of $104000 \mathrm{~km}^{2}{ }^{5}$

\section{Results and discussion}

The average seasonal cycle of $\mathrm{CO}_{2}$ fluxes (Figure 2) was calculated using the zonal averages. Summer (September - January) and winter (May August) were $\mathrm{CO}_{2}$ sinks with fluxes of -5.8 and $-3.4 \mathrm{mmol} \mathrm{C} / \mathrm{m}^{2}$ per day, respectively (see Table 1 for summary). Autumn (February - April) was the only season where the flux was positive $\left(1.4 \mathrm{mmol} \mathrm{C} / \mathrm{m}^{2}\right.$ per day), which means that the region was a $\mathrm{CO}_{2}$ source over this period. These estimates showed the same decreasing trend from summer to winter as that reported by Chen and Borges ${ }^{4}$, namely a decrease in uptake from $-11.0 \mathrm{mmol} \mathrm{C} / \mathrm{m}^{2}$ per day in summer to $-5.5 \mathrm{mmol} \mathrm{C} /$ $\mathrm{m}^{2}$ per day in winter (note that uptake is negative and outgassing is positive). The net annual flux estimate for the region was $-1.4 \pm 0.6$ $\mathrm{mol} \mathrm{C} / \mathrm{m}^{2}$ per year - equivalent to the uptake of $1.8 \pm 0.8 \mathrm{Mt} \mathrm{C} /$ year for 2010. The former value compares well with those reported in previous studies on the region (Table 1). ${ }^{5,12,13} \mathrm{~A}$ great deal of interannual variability was observed during 2006-2007 as a result of changes in upwelling intensity; however, the region remained a sink over the entire period. ${ }^{13}$ This finding is in contrast to those of this study, where autumn was found to be a $\mathrm{CO}_{2}$ source to the atmosphere. This difference could be a result of interannual variability or because the study by González-Dávila et al. ${ }^{13}$ was biased towards the offshore region, where waters were consistently a carbon sink (Figure 2).

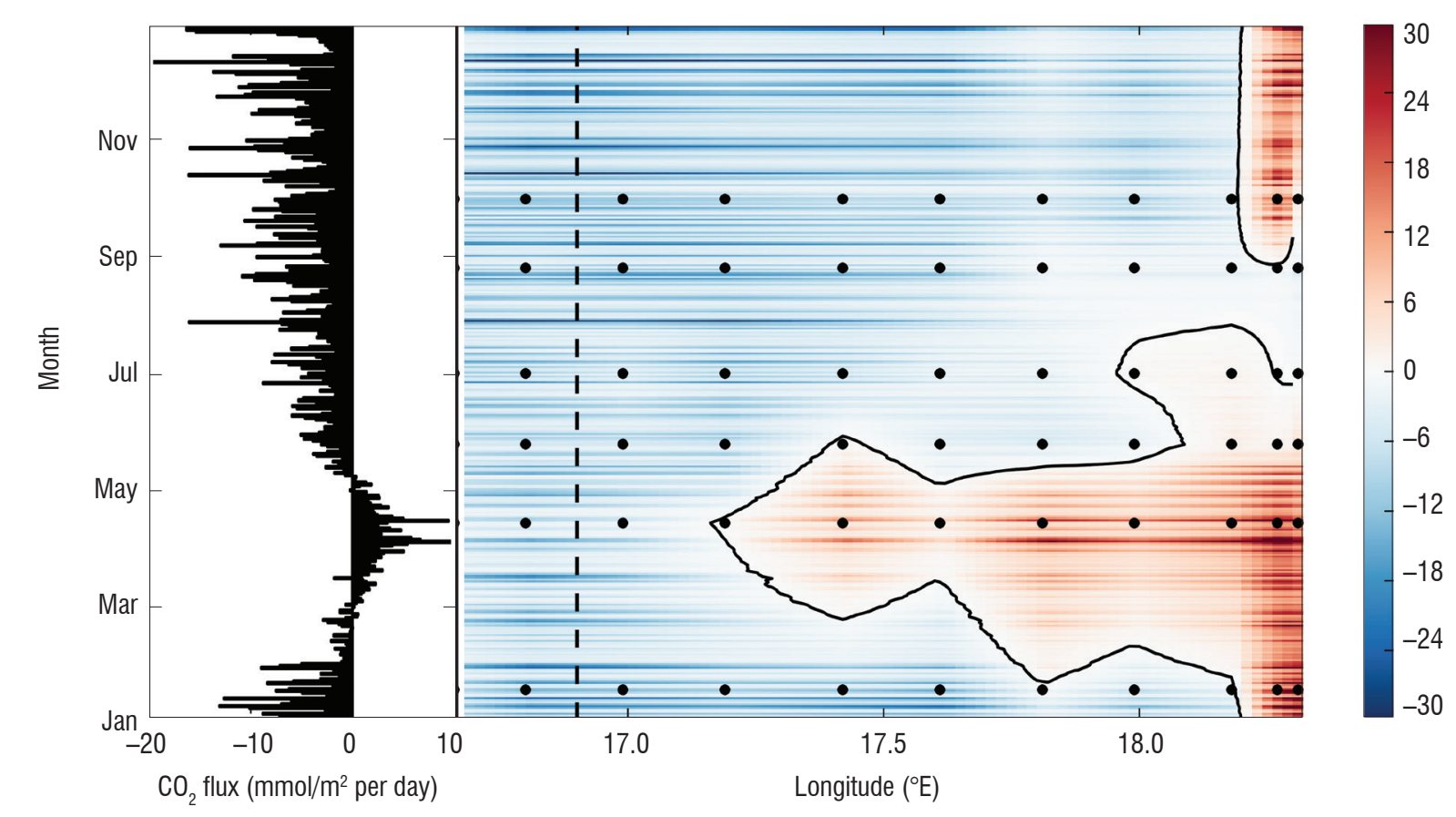

Figure 2: $\quad \mathrm{CO}_{2}$ flux ( $\mathrm{mmol} / \mathrm{m}^{2}$ per day) along the St. Helena Bay Monitoring line for daily winds (right). Red is outgassing and blue is ingassing. The dot markers show the sample location and date and the dashed line shows the approximate location of sampling by González-Dávila et al. ${ }^{13}$ The average daily flux is plotted on the left. 
Table 1: Air-sea fluxes reported in previous studies and found in this study

\begin{tabular}{|c|c|c|c|c|}
\hline \multirow[t]{2}{*}{ Study } & $\begin{array}{l}\text { Spring/ } \\
\text { Summer }\end{array}$ & Autumn & Winter & \multirow{2}{*}{$\begin{array}{c}\begin{array}{c}\text { Mean } \\
\text { annual } \\
\text { flux }\end{array} \\
\text { (mol C/m² } \\
\text { per year) }\end{array}$} \\
\hline & \multicolumn{3}{|c|}{ (mmol C/m² per day) } & \\
\hline Monteiro 5 & - & - & - & -1.36 \\
\hline $\begin{array}{l}\text { Santana-Casiano } \\
\text { et al. }{ }^{12}\end{array}$ & -11 & - & -5.5 & -1.62 \\
\hline González-Dávila et al. ${ }^{13}$ & - & - & - & $\begin{array}{c}-1.17 \text { to } \\
-3.24\end{array}$ \\
\hline This study & -8.31 & 4.13 & -5.15 & -1.53 \\
\hline
\end{tabular}

The boundary between the offshore sink and nearshore source regions migrated considerably throughout 2010 (Figure 2). The extent of this boundary was determined by the relative magnitudes of primary productivity and remineralisation during the seasonal cycle as well as the cumulative intensity of seasonal upwelling. Remineralisation of organic matter occurred predominantly in bottom waters and sediments resulting in increased $\mathrm{pCO}_{2}{ }^{20} \mathrm{~A}$ cross section of the SHBML (Figure 3) depicts the remineralisation of exported particulate organic matter to DIC in bottom waters. The idealised circulation depicted in this figure brings $\mathrm{CO}_{2}$-enriched water to the surface in the nearshore region, where surface processes such as primary productivity decrease the partial pressure of $\mathrm{CO}_{2}$. The balance between these two dominant counteracting processes (remineralisation and primary production) plays a first-order role in determining the $\mathrm{CO}_{2}$ flux with the atmosphere, but lower-order contributors to the marine carbonate system cannot be overlooked.

The contribution of the processes that alter the $\mathrm{pCO}_{2}$ was calculated by analysis of changes in nutrient, DIC and TA ratios and their impact on $\mathrm{pCO}_{2}$ changes (Table 2 and Figure 4). The two most dominant processes were primary production and remineralisation. The effect of primary production ranged between -98 and $-28 \mu \mathrm{atm} \mathrm{CO}_{2} /$ day and aerobic remineralisation between 39 and $95 \mu \mathrm{atm} \mathrm{CO}_{2} /$ day. These processes are simple to understand as a large change in DIC by primary production or remineralisation leads to a proportional change in $\mathrm{pCO}_{2}$. This relationship is not true for the other processes where simultaneous increases or decreases of DIC or TA lead to a complex response of $\mathrm{pCO}_{2}$ - an increase in DIC leads to increased $\mathrm{pCO}_{2}$, whereas an increase in TA leads to a decrease in $\mathrm{pCO}_{2}$. It is then the ratio of change of DIC to $\mathrm{TA}$, which is specific to each process, that determines the $\mathrm{pCO}_{2}$ (Table 2). Denitrification was marginal in summer and autumn contributing ca. $5.4 \mu \mathrm{atm} \mathrm{CO}_{2} /$ day and negligible during winter. In contrast to denitrification, sulphate reduction led to decreased $\mathrm{pCO}_{2}$ (as a result of increased $\mathrm{TA}$ ), with the most dominant contribution, reducing $\mathrm{pCO}_{2}$ by $-11 \mu$ atm $\mathrm{CO}_{2} /$ day, occurring in autumn. Sulphate reduction during summer and winter $\left(-5 \mathrm{CO}_{2} /\right.$ day and $-4 \mu \mathrm{atm} \mathrm{CO}_{2} /$ day) contributed in the same order of magnitude to denitrification, mitigating the increased $\mathrm{pCO}_{2}$. Calcification, resulting in a decrease in TA, led to strong increases in surface $\mathrm{pCO}_{2}$ during autumn, ${ }^{21}$ equating to $50 \%$ of the DIC uptake by primary production. This proportion was significantly greater than that found in studies in the North Atlantic that reported significantly lower net community calcification than net community production $(13 \%){ }^{22}$ Evidently, autumn biogeochemistry was dissimilar from the other seasons because of intensification of a seasonal sub-thermocline oxygen minimum zone. ${ }^{23}$ Reduced upwelling and mixing in autumn led to intense and persistent stratification, resulting in decreased ventilation of sub-thermocline waters. Aerobic remineralisation eventually depleted oxygen to a level where anaerobic remineralisation became viable. Anaerobic processes such as denitrification and calcification increased the $\mathrm{pCO}_{2}$, which was upwelled to surface waters. ${ }^{20}$ The resulting air-sea $\mathrm{CO}_{2}$ fluxes were low given the aerobic remineralisation fluxes $(-27 \mu \mathrm{atm}$ $\mathrm{CO}_{2}^{2}$ /day to $1 \mu \mathrm{atm} \mathrm{CO}_{2} /$ day). However, it was the counteracting primary production that took up DIC and decreased $\mathrm{pCO}_{2}$ that resulted in the low $\mathrm{CO}_{2}$ fluxes.

Studies suggest that ocean-atmosphere heat fluxes, shelf width, wind stress variability and shelf boundary exchange mechanisms may be important in determining the direction and magnitude of flux.23-25 These factors explain the inconsistent $\mathrm{CO}_{2}$ flux results among eastern boundary current systems at similar latitudes, such as the Humboldt $\left(-0.3-1.94 \mathrm{~mol} \mathrm{C} / \mathrm{m}^{2} \text { per year }\right)^{26}$, Californian $\left(2.2-0.7 \mathrm{~mol} \mathrm{C} / \mathrm{m}^{2}\right.$ per year) ${ }^{4}$ and Galician $\left(-2.2 \mathrm{~mol} \mathrm{C} / \mathrm{m}^{-2} \text { per year }\right)^{4}$ as well as the difference between the two Benguela subsystems. ${ }^{12}$ The southern Benguela may export a higher proportion of its new production across the oceanshelf boundary compared to its northern counterpart, where trapping of particular organic carbon in alongshore inshore sediment belts supports persistent anaerobic remineralisation. ${ }^{23}$ Widespread denitrification is more intense in the northern Benguela upwelling system, leading to nitrate deficits, thus resulting in the region being a $\mathrm{CO}_{2}$ source. ${ }^{20,24}$

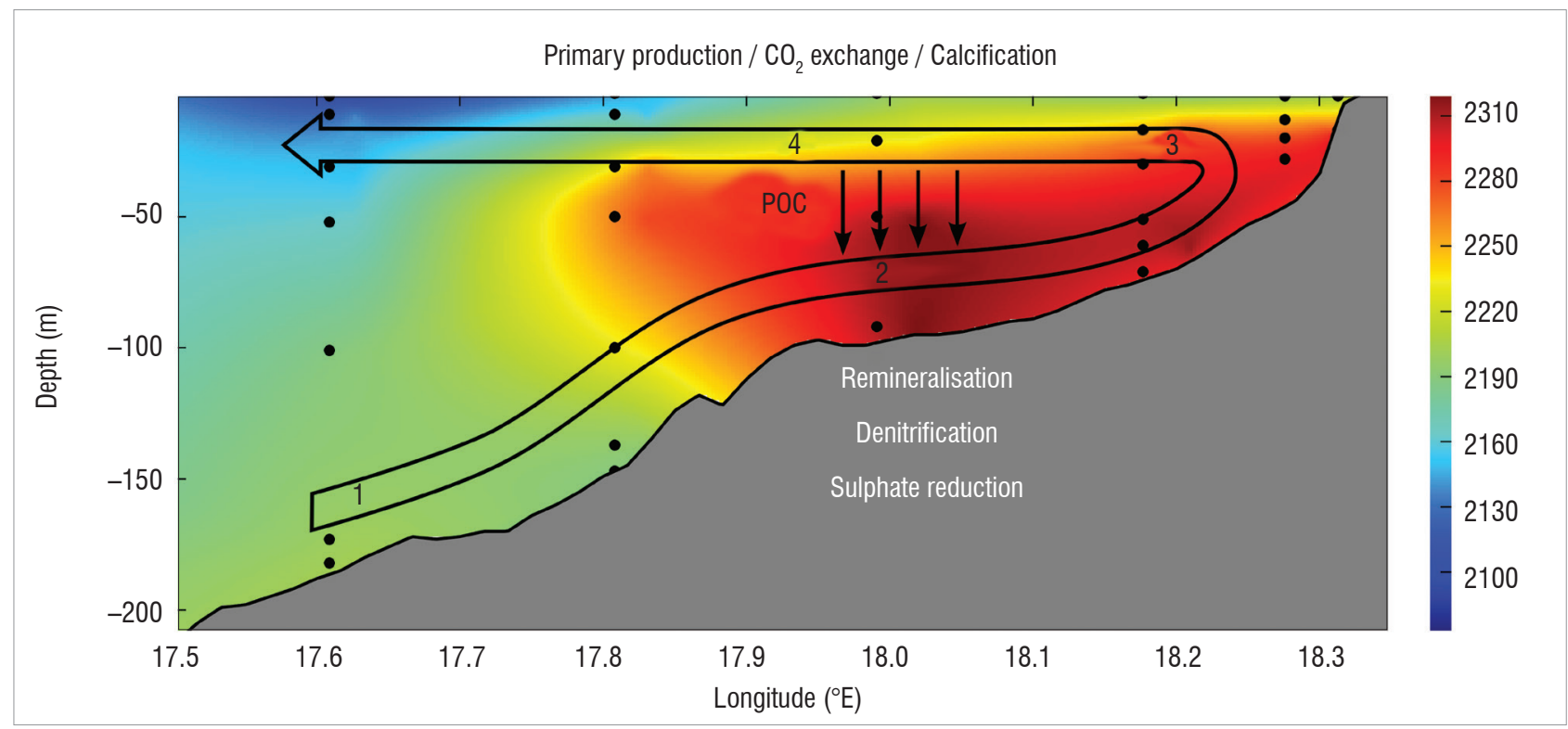

Figure 3: A vertical section of dissolved inorganic carbon $(\mu \mathrm{mol} / \mathrm{kg})$ for April 2010. The thick arrow shows the idealised cross-shelf flow driven by upwelling. The small arrows depict particulate organic carbon (POC) sinking. The surface processes that alter $\mathrm{pCO}_{2}$ in the surface are shown above the plot and those that affect $\mathrm{pCO}_{2}$ in the ocean below are shown at the bottom. 
Evidence from the southern and northern Benguela subsystems then agrees with the idealised notion that temperate shelf systems are sinks, while those at lower latitudes are sources. ${ }^{4}$ The exact mechanism that enhances shelf export in the southern Benguela is unclear, but the high eddy kinetic energy in this sector suggests that eddy-driven transport may be an important vector, as has been observed in the Californian upwelling system. ${ }^{27,28}$ Previous estimates of $\mathrm{CO}_{2}$ export across the shelf boundary are larger by an order of magnitude (7.2-39.0 Mt C/year) than the sea-air $\mathrm{CO}_{2}$ fluxes presented in this study, supporting a finding of offshore transport of $\mathrm{CO}_{2} \cdot{ }^{29}$

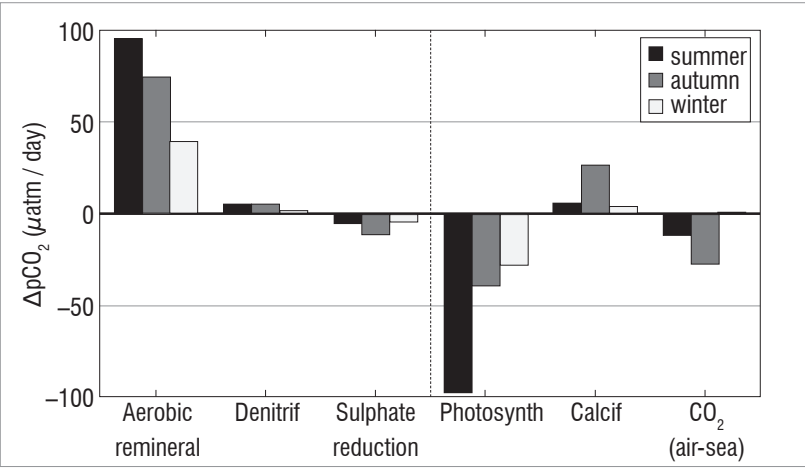

Figure 4: Average rates of change of $\mathrm{pCO}_{2}$ by primary production, aerobic remineralisation, denitrification, calcification and air-sea $\mathrm{CO}_{2}$ flux for the three seasons. Photosynthesis and denitrification were consistently the largest contributors to net flux.

Table 2: A summary of the method used to find the contribution of the listed processes to dissolved inorganic carbon

\begin{tabular}{|c|c|c|c|c|}
\hline \multirow{2}{*}{$\begin{array}{l}\begin{array}{l}\text { Surface } \\
\text { processes }\end{array} \\
\text { Photosynthesis }\end{array}$} & \multicolumn{2}{|c|}{$\Delta D I C=P s+C l+F I$} & \multirow{2}{*}{$\begin{array}{l}\Delta \text { DIC } \\
-106\end{array}$} & \multirow{2}{*}{$\begin{array}{r}\Delta \mathrm{TA} \\
16\end{array}$} \\
\hline & Ps & $\triangle P O_{4}^{-} \times C: P$ & & \\
\hline Calcification & $\mathrm{Cl}$ & $-\Delta n T A * \div 2$ & -1 & -2 \\
\hline Carbon flux & $\mathrm{Fl}$ & $\mathrm{FCO}_{2} \div \mathrm{MLD} \times \mathrm{a}$ & -1 & - \\
\hline $\begin{array}{l}\text { Subsurface } \\
\text { processes }\end{array}$ & \multicolumn{2}{|c|}{$\Delta D I C=R m+D n+C d+S r$} & $\Delta D I C$ & $\Delta \mathrm{TA}$ \\
\hline $\begin{array}{l}\text { Aerobic } \\
\text { remineralisation }\end{array}$ & $\mathrm{Rm}$ & $\triangle P O_{4}^{-} \times C: P$ & 106 & -16 \\
\hline Denitrification & Dn & $-5 / 4 \cdot\left(\left[N O_{3}^{-}\right]-N: P \cdot\left[P O_{4}^{-}\right]\right)$ & 5 & 4 \\
\hline $\begin{array}{l}\text { Sulphate } \\
\text { reduction }{ }^{\dagger}\end{array}$ & $\mathrm{Sr}$ & $\Delta n T A \div 2$ & 1 & 2 \\
\hline
\end{tabular}

$n T A^{*}$ is the salinity normalised total alkalinity corrected for nitrate uptake. Total alkalinity was calculated using the relative change in dissolved inorganic carbon for each process (as shown on the right for standard Redfield ratios).

MLD, mixed layer depth.

'Sulphate reduction and calcite dissolution could not be distinguished given the measured variables; however, calcite saturation state was never observed to be below 1, therefore sulphate reduction was assumed.

Extrapolating the findings of this study to other coastal regions of South Africa should be done with caution. The southern coast bears resemblance to the west coast and is likely to also be a weak $\mathrm{CO}_{2}$ sink. ${ }^{30}$ The same does not hold for the subtropical east coast where a narrow shelf and river inputs present an entirely different physical setting. ${ }^{31}$ A separate study would have to be conducted on these regions to effectively determine whether the South African continental margins are a net sink or source of $\mathrm{CO}_{2}$.

\section{Conclusion}

The seasonality of air-sea $\mathrm{CO}_{2}$ flux and biogeochemical drivers of the marine carbonate system of the southern Benguela upwelling system were investigated. With the inclusion of the two previous estimates, the magnitude of $\mathrm{CO}_{2}$ flux ranges from -1.7 to $-2.0 \mathrm{Mt} \mathrm{C} /$ year. ${ }^{5,12,13}$ The reason for this modest sink, in the context of high primary productivity rates, is that the net annual carbon uptake is balanced by the nearly equally large remineralised carbon fluxes from the sediments and sub-thermocline waters.

Now, more than ever, it is important to strengthen long-term observations of our coastal-shelf regions as reports of decreasing fish stocks in the southern Benguela reveal a changing ecosystem. ${ }^{9}$ The larger impacts of ocean acidification linked to increased anthropogenic $\mathrm{CO}_{2}$ emissions will increase the stresses on these overexploited stocks. Moreover, naturally elevated Revelle factors make this region particularly sensitive to increased atmospheric $\mathrm{pCO}_{2}$. Changing driving mechanisms (winds) and increasing atmospheric $\mathrm{CO}_{2}$, could alter this 'steady state' in the southern Benguela, enhancing the sink or source fluxes depending on which part of the carbon cycle or eddy driven shelf export is altered. The evolution of the dynamic carbon cycle of the southern Benguela region may also provide insight into future changes of ocean carbon chemistry in other comparable upwelling systems regions.

\section{Acknowledgements}

We thank Dr Howard Waldron for his support and co-supervision and the Departments of Environment (Ocean and Coasts Branch) and Agriculture and Fisheries for allowing the sampling of the St. Helena Bay Monitoring Line to be undertaken onboard their ships. We are thankful to the National Research Foundation for a studentship to L.G. and the Council for Scientific and Industrial Research for a Parliamentary Grant. This research was conducted as part of the Southern Ocean Carbon - Climate Observatory (SOCCO) programme.

\section{Authors' contributions}

L.G. wrote the manuscript based on work from his MSc dissertation. P.M.S.M. supervised the work and reviewed and edited the manuscript.

\section{References}

1. Doney SC, Fabry VJ, Feely RA, Kleypas J. Ocean acidification: The other CO problem. Annu Rev Mar Sci. 2009;1:169-192. http://dx.doi.org/10.1146/ annurev.marine.010908.163834

2. Cicerone R, Orr JC, Brewer PG, Haugan P, Merlivat L, Ohsumi T, et al. The ocean in a high- $\mathrm{CO}_{2}$ world. Oceanography. 2004;17(3):1. http://dx.doi. org/10.5670/oceanog.2004.35

3. Takahashi T, Sutherland SC, Wanninkhof R, Sweeny C, Feely RA, Chipman $\mathrm{DW}$, et al. Climatological mean and decadal change in surface ocean $\mathrm{pCO}_{2}$, and net sea-air $\mathrm{CO}_{2}$ flux over the global oceans. Deep-Sea Res Pt II. 2009;56(8-10):554-577. http://dx.doi.org/10.1016/j.dsr2.2008.12.009

4. Chen CA, Borges AV. Reconciling opposing views on carbon cycling in the coastal ocean: Continental shelves as sinks and near-shore ecosystems as

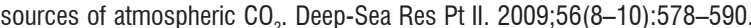
http://dx.doi.org/10.1016/j.dsr2.2009.01.001

5. Monteiro P. Eastern boundary currents: The Benguela Current system. In: Lit KK, Atkinson L, Quiñones R, Talaue-McManus L, editors. Carbon and nutrient fluxes in continental margins: A global synthesis. New York: Springer; 2010. p. $64-77$.

6. Globalview-CO Cooperative Atmospheric Data Integration Project - Carbon dioxide [homepage on the Internet]. c2011 [cited 2011 Oct 13]. Available from: www.esrl.noaa.gov/gmd/ccgg/globalviewftp.cmdl.noaa.gov

7. Hietkamp S, Engelbrecht A, Scholes B, Golding A. Potential for sequestration of carbon dioxide in South Africa carbon capture and storage in South Africa. Science real and relevant: 2nd CSIR Biennial Conference; 2008 Nov 17-18; Pretoria, South Africa. Pretoria: CSIR; 2008. p. 7.

8. Nellemann C, Corcoran E, Duarte CM, Valdés CM, De Young C, Fonseca L, et al. Blue carbon: A rapid response assessment [homepage on the Internet]. c2009 [cited 2012 May 10]. Available from: www.grida.no 
9. Hutchings L, Van Der Lingen CD, Shannon L, Crawford RJM, Verheye HMS, Bartholomae $\mathrm{CH}$, et al. The Benguela Current: An ecosystem of four components. Prog Oceanogr. 2009;83(1-4):15-32. http://dx.doi. org/10.1016/j.pocean.2009.07.046

10. Waldron $H$, Probyn T. Nitrate supply and potential new production in the Benguela upwelling system. S Afr J Mar Sci. 1992;12:29-39. http://dx.doi. org/10.2989/02577619209504688

11. Shillington FA, Reason CJC, Duncombe Rae CM, Florenchie P, Penven P. Large scale physical variability of the Benguela Current Large Marine Ecosystem (BCLME). Large Mar Ecosyst. 2006;14:49-70. http://dx.doi.org/10.1016/ S1570-0461(06)80009-1

12. Santana-Casiano JM, González-Dávila M, Ucha IR. Carbon dioxide fluxes in the Benguela upwelling system during winter and spring: A comparison between 2005 and 2006. Deep-Sea Res Pt II. 2009;56(8-10):533-541. http://dx.doi.org/10.1016/j.dsr2.2008.12.010

13. González-Dávila M, Santana-Casiano JM, Ucha IR. Seasonal variability of $\mathrm{fCO}_{2}$ in the Angola-Benguela region. Prog 0ceanogr. 2009;83(1-4):124-133. http://dx.doi.org/10.1016/j.pocean.2009.07.033

14. Mintrop L. VINDTA: Manual for versions 3S and 3C. Kiel: Germany; 2010.

15. Dickson AG, Millero FJ. A comparison of the equilibrium constants for the dissociation of carbonic acid in seawater media. Deep-Sea Res Pt I. 1987;34(10):1733-1743. http://dx.doi.org/10.1016/0198-0149(87)90021-5

16. Grasshoff K, Ehrhardt M, Kremling K, editors. Methods of seawater analysis. Weinheim: Wiley-VCH; 1999. http://dx.doi.org/10.1002/9783527613984

17. Wanninkhof R, Asher WE, Ho DT, Sweeny C, McGillis WR. Advances in quantifying air-sea gas exchange and environmental forcing. Annu Rev Mar Sci. 2009;1:213-244. http://dx.doi.org/10.1146/annurev. marine.010908.163742

18. Weiss $R$, Price BA. Nitrous oxide solubility in water and seawater. Mar Chem. 1980;8(4):347-359. http://dx.doi.org/10.1016/0304-4203(80)90024-9

19. Atlas R, Hoffman RN, Ardizzone J, Leidner SM, Jusem JC, Smith DK, et al. A cross-calibrated, multiplatform ocean surface wind velocity product for meteorological and oceanographic applications. Bull Am Meteorol Soc. 2011;92(2):157-174. http://dx.doi.org/10.1175/2010BAMS2946.1

20. Tyrrell T, Lucas M. Geochemical evidence of denitrification in the Benguela upwelling system. Cont Shelf Res. 2002;22(17):2497-2511. http://dx.doi. org/10.1016/S0278-4343(02)00077-8
21. Weeks S, Pitcher G, Bernard S. Satellite monitoring of the evolution of a coccolithophorid bloom in the southern Benguela upwelling system. Oceanography. 2011;17(1):83-89. http://dx.doi.org/10.5670/ oceanog.2004.70

22. Suykens K, Delille B, Chou L, De Bodt C, Harlay J, Borges AV. Dissolved inorganic carbon dynamics and air-sea carbon dioxide fluxes during coccolithophore blooms in the Northwest European continental margin (northern Bay of Biscay). Global Biogeochem Cy. 2010;24:1-14. http:// dx.doi.org/10.1029/2009GB003730

23. Monteiro PMS, Dewitte B, Scranton MI, Paulmier A, Van der Plas AK. The role of open ocean boundary forcing on seasonal to decadal-scale variability and long-term change of natural shelf hypoxia. Environ Res Lett. 2011;6:18. http://dx.doi.org/10.1088/1748-9326/6/2/025002

24. Friederich GE, Ledesma J, Ulloa 0, Chavez FP. Air-sea carbon dioxide fluxes in the coastal southeastern tropical Pacific. Prog Oceanogr. 2008;79(2-4):156166. http://dx.doi.org/10.1016/j.pocean.2008.10.001

25. Ianson D, Feely RA, Sabine CL, Juranek LW. Features of coastal upwelling regions that determine net air-sea $\mathrm{CO}_{2}$ flux. J Oceanogr. 2009;65:677-687. http://dx.doi.org/10.1007/s10872-009-0059-z

26. Quiñones R, Gutiérrez PA, Daneri G, Guitiérrez Aguilar D, González HE, Chavez FP. Eastern Boundary Currents: The Humboldt Current System. In: Liu KK, Atkinson L, Quiñones R, Talaue-McManus L, editors. Carbon and nutrient fluxes in continental margins: A global synthesis. New York: Springer; 2010. p. 44-64. http://dx.doi.org/10.1007/978-3-540-92735-8_2

27. Boebel 0, Lutjeharms J, Schmid C, Zenk W, Rossby T, Barron C. The Cape Cauldron: a regime of turbulent inter-ocean exchange. Deep-Sea Res Pt II. 2003;50(1):57-86. http://dx.doi.org/10.1016/S0967-0645(02)00379-X

28. Gruber N, Lachkar Z, Frenzel H, Marchesiello P, Münnich M, McWilliams JC et al. Eddy-induced reduction of biological production in eastern boundary upwelling systems. Nat Geosci. 2011:4(11):787-792. http://dx.doi. org/10.1038/nge01273

29. Waldron HN, Monteiro PMS, Swart NC. Carbon export and sequestration in the southern Benguela upwelling system: Lower and upper estimates. Ocean Sci. 2009;5:711-718. http://dx.doi.org/10.5194/os-5-711-2009

30. Schumann EH, Perrins LA, Hunter IT. Upwelling along the south coast of the Cape Province, South Africa. S Afr J Sci. 1982;78:238-242.

31. Baird D. Indian Ocean margins. In: Liu KK, Atkinson L, Quiñones R, TalaueMcManus $L$, editors. Carbon and nutrient fluxes in continental margins: $A$ global synthesis. New York: Springer; 2010, p. 64-77. 